\title{
Состояние и перспективы развития овощеводства в странах Евразийского экономического союза
}

\section{State and prospects of development of vegetable growing in the countries of the Eurasian economic Union}

\author{
Разин А.Ф., Мещерякова Р.А., Шатилов М.В., Разин О.А., \\ Сурихина Т.Н., Телегина Г.А.
}

\section{Аннотация}

Целями основания Евразийского экономического союза (ЕАЭС) было создание условий для стабильного развития экономик государств - членов союза в интересах повышения жизненного уровня их населения, стремление к формированию единого рынка товаров, услуг, капитала и трудовых ресурсов, всесторонняя модернизация, кооперация и повышение конкурентоспособности национальных экономик государств - членов союза в условиях глобальной экономики. Цель исследования - проанализировать состояние овощеводства и обеспеченность овощами населения стран - членов Евразийского экономического союза в составе Республик Армения, Беларусь, Казахстан, Кыргызской Республики и Российской Федерации. По итогам проведенного анализа установлено, что в период 2013-2017 годов посевные площади овощных культур в ЕАЭС выросли на 7,7\% и превысили 1 млн га. В 2018 году валовой сбор овощей увеличился на 13\% до 24,1 млн т. При этом более $62 \%$ овощей производится в хозяйствах населения и $22 \%$ в КФХ, что говорит о мелкотоварном характере производства и низкой товарности продукции в ЕАЭС. Лидер по производству овощей на душу населения - Армения (324 кг/чел.), наименьшее значение в России - 111 кг/чел., среднее по ЕАЭС - 131 кг/чел. Урожай овощных культур увеличился во всех государствах - членах союза, за исключением Армении, где этот показатель максимальный в рамках союза - 286 кг/га. Объем импорта свежих овощей из третьих стран в период 2014-2017 годах снизился на 16,8\% в натуральном выражении и на 33,4\% до 1,8 млрд \$ в денежном исчислении, что обусловлено введением продуктового эмбарго и снижением объема импорта в Россию практически в два раза. Взаимная торговля (по экспорту) свежими овощами увеличилась на $36,4 \%$ до 241 млн \$. Около 77\% объема взаимной торговли приходится на поставки из Беларуси, при этом более 90\% объема взаимной торговли овощами направлены на рынок России. Одной из мер по поддержке и развитию отрасли овощеводства могут стать: снижение доли посредников в потребительской цене на овощи, строительство тепличных комплексов для производства отечественных овощей в несезонный период и овощехранилищ и др.

Ключевые слова: овощи, Евразийский экономический союз, производство, экспорт, импорт, торговля.

Для цитирования: Состояние и перспективы развития овощеводства в странах Евразийского экономического союза / А.Ф. Разин, Р.А. Мещерякова, М.В. Шатилов , Т.Н. Сурихина , Г.А. Телегина // Картофель и овощи. 2020. №3. С. 11-15. https://doi. org/10.25630/PAV.2020.45.19.002

\author{
Razin A.F., Meshcheryakova R.A., Shatilov M.V., Razin O.A. \\ Surikhina T.N., Telegina G.A.
}

\section{Abstract}

The objectives of founding the Eurasian economic Union (EAEU) was the creation of conditions for stable development of the economies of the member States of the Union to improve the living standards of their populations, the desire to create a common market of goods, services, capital and labor resources, comprehensive modernization, cooperation and competitiveness of national economies of member States of the Union in the global economy. The purpose of the study is to analyze the state of vegetable production and the availability of vegetables for the population of the member States of the Eurasian economic Union in the Republics of Armenia, Belarus, Kazakhstan, the Kyrgyz Republic and the Russian Federation. According to the results of the analysis, it was found that in the period 2013-2017, the acreage of vegetable crops in the EAEU increased by $7.7 \%$ and exceeded 1 million hectares. In 2018, the gross harvest of vegetables increased by $13 \%$ to 24.1 million tons. at the same time, more than $62 \%$ of vegetables are produced in households and $22 \%$ in farms, which indicates the small-scale nature of production and low marketability of products in the EAEU. The leader in the production of vegetables per capita is Armenia ( $324 \mathrm{~kg} /$ person), the lowest value in Russia is $111 \mathrm{~kg} /$ person, the average for the EEU is $131 \mathrm{~kg} /$ person. The yield of vegetable crops increased in all member States of the Union, with the exception of Armenia, where this figure is the maximum within the Union $-286 \mathrm{~kg} / \mathrm{ha}$. The volume of imports of fresh vegetables from third countries in the period 2014-2017 decreased by $16.8 \%$ in physical terms and by $33.4 \%$ to $\$ 1.8$ billion in monetary terms, due to the introduction of the food embargo and a decrease in the volume of imports to Russia almost twice. Mutual trade (by export) in fresh vegetables increased by $36.4 \%$ to $\$ 241$ million. About $77 \%$ of the volume of mutual trade comes from Belarus, while more than $90 \%$ of the volume of mutual trade in vegetables is directed to the Russian market. One of the measures to support and develop the vegetable industry can be: reducing the share of intermediaries in the consumer price of vegetables, construction of greenhouse complexes for the production of domestic vegetables in the off-season period and vegetable stores, etc.

Keywords: vegetables, Eurasian economic Union, production, export, import, trade.

For citing: State and prospects of development of vegetable growing in the countries of the Eurasian economic Union / A.F. Razin, R.A. Meshcheryakova, M.V. Shatilov, T.N. Surikhina, G.A. Telegina // Potato and vegetables. 2020. №3. Pp. 11-15. https://doi.org/10.25630/ PAV.2020.45.19.002 (In Russ.) вразийский экономический союз (ЕАЭС) - международная организация региональной экономической интеграции, обладающая международной правосубъектностью и учрежденная Договором об Евразийском экономическом союзе [1].

В ЕАЭС обеспечивается свобода движения товаров, услуг, капи- тала и рабочей силы, а также проводится скоординированная, согласованная или единая политика в отраслях экономики. Государства - члены Евразийского экономического союза: Республика Армения, Республика Беларусь, Республика Казахстан, Кыргызская Республика и Российская Федерация. ЕАЭС со- здан в целях всесторонней модернизации, кооперации и повышения конкурентоспособности национальных экономик и создания условий для стабильного развития в интересах повышения жизненного уровня населения государств - членов Союза.

Цель исследования - проанализировать состояние овощеводства 
и обеспеченность овощами населения стран - членов Евразийского экономического союза в составе Республик Армения, Беларусь, Казахстан, Кыргызской Республики и Российской Федерации.

Условия, материалы и методы исследований

Использовали следующие методы: статистическо-экономический, расчетно-конструктивный, монографический, балансовый, абстрактно-логический. Применяли методические рекомендации по разработке прогноза производства и потребления основных видов с. - х. продукции, сырья и продовольствия в стране, официальные данные Министерства экономического развития РФ, материалы Парламентских слушаний, Минсельхоза РФ, материалы периодической печати, научных семинаров, конференций, симпозиумов, отражающие различные аспекты исследуемой проблемы.

\section{Результаты исследований}

C момента озвучивания идеи о формировании Евразийского союза государств Президентом Казахстана Н.А. Назарбаевым (29 марта 1994 года) до подписания Договора о Евразийском экономическом союзе (ЕАЭС) (29 мая 2014 года) на заседании Высшего Евразийского экономического совета прошло 20 лет.

Цель основания ЕАЭС - создание условий для стабильного развития экономик государств - членов в интересах повышения жизненного уровня их населения, стремление к формированию единого рынка товаров, услуг, капитала и трудовых ресурсов, всесторонняя модернизация, кооперация и повышение конкурентоспособности национальных экономик государств - членов ЕАЭС в условиях глобальной экономики.

Задуманный как высшая форма равноправного и взаимовыгодного сотрудничества, Евразийский союз государств, по сути - модель цивилизованных взаимосвязей независимых государств на постсоветском пространстве, при безусловном сохранении ими суверенитета, территориальной целостности и нерушимости границ. Эти принципы постепенно воплощаются в жизнь.

В 1995 году Республика Беларусь, Республика Казахстан и Российская Федерация подписали Соглашение о Таможенном союзе (ТС), нацеленное на устранение препятствий для свободного экономического взаимодействия между хозяйствующи- ми субъектами сторон, обеспечение свободного товарообмена и добросовестной конкуренции и, в конечном итоге, на устойчивое развитие экономик его государств-членов. Подписанное Соглашение «тройки» определило то интеграционное ядро, которое в настоящее время стало двигателем интеграционных процессов на пространстве Евразии.

В целях эффективного продвижения процесса формирования Таможенного союза (ТС) и Единого экономического пространства (ЕЭП) 10 октября 2000 года Президентами пяти государств (Республики Беларусь, Казахстана, Кыргызстана и Таджикистана, Российской Федерации) было учреждено Евразийское экономическое сообщество (ЕврАзЭС).

C момента подписания Соглашения о ТС (1995 год) и формирования ЕЭП (2013 год) Правительства сторон провели работу по подготовке правовой и нормативной базы ТС и ЕЭК.

В подписанном в октябре 2007 году Договоре о создании единой таможенной территории и формировании ТС трех государств (Республики Беларусь, Казахстана и Российской Федерации) была поставлена цель - обеспечить свободное перемещение товаров во взаимной торговле и благоприятных условий торговли Таможенного союза с третьими странами, а также развитие экономической интеграции.

Таможенный союз трех государств начал функционировать в январе 2010 года: введен в действие Единый таможенный тариф, отменены таможенное оформление и таможенный контроль на внутренних границах, обеспечено беспрепятственное движение товаров на территории трех государств. В декабре приняты 17 базовых международных договоров, создающих основу для начала функционирования ЕЭП, а также подписана Декларация о формировании ЕЭП Республики Беларусь, Республики Казахстан и Российской Федерации. В декабре 2011 года президенты трех государств приняли решения о вступлении в силу с 1 января 2012 года международных договоров, формирующих ЕЭП Республик Беларусь, Казахстан и Российской Федерации.

В августе 2006 года в ходе неформального саммита в Сочи главами государств - членов ЕврАзЭС принято решение об активизации Республикой Беларусь, Республикой
Казахстан и Российской Федерацией работы по формированию Таможенного союза в формате «тройки» с последующим присоединением Кыргызской Республики и Республики Таджикистан по мере готовности их экономик.

В 2015 году вступил в силу Договор о Евразийском экономическом союзе (ЕАЭС, Союз). К нему присоединились Республика Армения и Кыргызская Республика [1].

В целях обеспечения развития агропромышленного комплекса стран ЕАЭС и экономической интеграции проводится согласованная агропромышленная политика в соответствии с договором о ЕАЭС от 29 мая 2014 года: регулярные консультации представителей государств - членов ЕАЭС, в том числе по чувствительным с.- х. товарам, в перечень которых включены овощные и бахчевые культуры, взаимное предоставление странами ЕАЭС друг другу и Евразийскую экономическую комиссию планов развития производства овощей в целях эффективной реализации ресурсного потенциала стран ЕАЭС, оптимизации объемов производства, удовлетворения потребности общего аграрного рынка и наращивания экспорта [2].

ЕАЭС ведет активную работу по расширению рамок взаимодействия с третьими странами. Так, в 2016 году вступило в силу Соглашение о зоне свободной торговли между ЕАЭС и Вьетнамом, в 2018 году Республике Молдова представлен статус страны-наблюдателя при ЕАЭС, подписано Соглашение о торгово-экономическом сотрудничестве между ЕАЭС и КНР, временное соглашение, ведущее к созданию зоны свободной торговли между ЕАЭС и Ираном.

На овощные культуры в государствах - членах ЕАЭС в 2017 году приходилось 0,9\% посевной (посадочной) площади, при этом в Республике Армения удельный вес овощных достиг 7,5\%. В этой стране более $60 \%$ посевной площади овощных приходится на области Армавир (40\%) и Арарат (23\%). В структуре посевных площадей овощных культур преобладают томаты (25\%), капуста (14\%), огурцы (9\%), баклажаны (7\%), перец (8\%) [3].

В Республике Беларусь почти 60\% посевных площадей овощных культур сосредоточены на юге страны в Брестской, Гомельской и Минской областях. В структуре посевных площадей овощных культур лидируют капуста (18\%), морковь и лук репча- 
тый (от 16\%), томаты (11\%), огурцы (9\%) [3].

В Республике Казахстан около $65 \%$ посевных площадей овощных культур сосредоточено на юго-востоке страны - в Южно-Казахстанской, Алматинской, Жамбылской и Восточно-Казахстанской областях. В структуре посевных площадей овощных культур основная доля приходится на томаты (20\%), лук репчатый $(19 \%)$, морковь $(14 \%)$, капусту (14\%), огурцы (12\%) [3].

В Кыргызской Республике 80\% посевных площадей приходится на Чуйскую (39\%), Джалал-Абадскую (23\%) и Ошскую (18\%) области. В структуре посевных площадей овощных культур основная доля приходится на томаты (21\%), лук репчатый (16\%), морковь (14\%), капусту (12\%), огурцы (11\%).

Около 80\% посевных площадей овощных культур Российской Федерации сосредоточено в юго-западных регионах страны - Южном, Северо-Кавказском и Поволжском, а также Центральном федеральных округах. В структуре посевных площадей овощных культур основная доля приходится на томаты (18\%), лук репчатый (13\%), морковь и огурцы (по 10\%).

Валовые сборы овощей в рамках ЕАЭС с 2013 по 2017 годы имели устойчивую тенденцию к росту и увеличились на $13 \%$ до 24 млн т, в т.ч. в Кыргызстане - на 23,3\% до 1,1 млн т, в Беларуси - на 20,3\% до 1,96 млн т, Казахстане - на $17 \%$ до 3,8 млн т. Сбор овощей сократился на $8 \%$ до 13,6 млн т в России, на $1,7 \%$ до 0,86 млн т в Армении. Тем не менее, Россия занимает среди стран Союза первое место по объему валового сбора овощей. В общем объеме про- изводства овощей на долю России приходится 65\%, Казахстана - 19\%, Беларуси - 8\%, Кыргызстана - 5\%, Армении - 3\%. В Казахстане валовой сбор овощей составляет 28,5\% российского показателя, в Беларуси $12,8 \%$, Кыргызстане - 8\%, Армении 4,6\%. По объему производства по культурам Россия также занимает лидирующую позицию. На ее долю приходится $45,1 \%$ производства огурца и 68,8\% капусты кочанной (табл. 1).

Мировой опыт показывает, что 70\% выращенных овощей продают свежими, 5-10\% идет в переработку, 20-25\% - на корм скоту и на выброс [4]. Примерно такие же показатели отмечаются и в странах Союза.

По данным национальных государственных статистических служб государств - членов Союза в среднем за период 2013-2017 годов $62,6 \%$ овощей выращивалось в ЛПХ, $22,5 \%$ - в КФХ и $14 \%$ - в СХО. При этом в Армении в ЛПХ выращивается 99,3\% овощей, в Беларуси $67,1 \%$, России - 66,5\%, Казахстане 40,7\%, Кыргызстане - 39,8\%, что свидетельствует о низкой товарности производства овощей в ЕАЭС. В КФХ выращивается 59,7\% овощей в Кыргызстане, 53,6\% в Казахстане, 18,4\% в Беларуси и 14\% - в России. Лидер по производству овощей в СХО - Россия, где выращивается $18,9 \%$ овощей, в Беларуси этот показатель равен $14,5 \%$, в Казахстане - 5,7\%.

В 2018 году доля валового сбора СХО в странах ЕАЭС колебалась от $1 \%$ в Кыргызстане до 26\% России.

Урожайность овощных культур в 2017 году во всех странах членах Союза выросла по сравнению с 2013 годом, в том числе и в Беларуси с 23,7 т/га до 29,5 т/га
$(24,5 \%)$, в Казахстане с 23,9 до 25,4 т/га (6,3\%), в Кыргызстане с 18,7 до 19,5 т/га (4,4\%), в России с 21,4 до 23,6 т/га (10,3\%). В Армении значение этого показателя снизилось с 33,4 до 28,6 т/га (на 14,2\%), однако оставалось одним из самых высоких наряду с урожайностью в Беларуси. Наибольший прирост урожайности в 2017 году установлен по сравнению с 2013 годом в Беларуси. В среднем по ЕАЭС на душу населения производится 131 кг в год, в т.ч. в Армении - 324 кг/чел., Казахстане - 213 кг/чел, Беларуси 199 кг/чел., в Кыргызстане 176 кг/чел., в России - 111 кг/чел. в год.

Согласно рекомендациям по рациональным нормам потребления пищевых продуктов, отвечающим современным требованиям здорового питания, необходимо потреблять овощей и бахчевых в среднем не менее 140 кг в год на душу населения. Этого норматива в ЕАЭС придерживается Россия, Беларусь и Кыргызстан. Армения и Казахстан придерживаются норматива, предусматривающего не менее 219 кг год на человека, согласно рекомендациям Всемирной организации здравоохранения (ВО3).

В Республиках Армения, Беларусь и Кыргызстане личное потребление равно или приблизилось к нормативу, а производство выше потребления соответственно в 2,0, 1,4 и 1,4 раза. В Казахстане фактическое производство овощей в 1,6 раза превышает потребности, а личное потребление в 1,4 раза превышает норматив. Россия - единственная страна среди членов Союза, в которой наблюдается недостаток как собственного производства (дефицит 19,8\%),

Таблица 1. Валовой сбор овощей в государствах - членах ЕАЭС в 2018 году (тыс.т., национальные государственные статистические службы государств - членов ЕАЭС)

\begin{tabular}{|c|c|c|c|c|c|c|c|c|c|c|c|c|c|}
\hline \multirow{3}{*}{$\begin{array}{c}\text { Вид } \\
\text { продукции }\end{array}$} & \multirow{3}{*}{$\begin{array}{c}\text { Арме- } \\
\text { ния } \\
\text { хозяйс- } \\
\text { тва всех } \\
\text { катего- } \\
\text { рий }\end{array}$} & \multicolumn{3}{|c|}{ Беларусь } & \multicolumn{3}{|c|}{ Казахстан } & \multicolumn{3}{|c|}{ Кыргызстан } & \multicolumn{3}{|c|}{ Россия } \\
\hline & & \multirow{2}{*}{$\begin{array}{c}\text { хозяйс- } \\
\text { тва всех } \\
\text { катего- } \\
\text { рий }\end{array}$} & \multicolumn{2}{|c|}{ в том числе: } & \multirow{2}{*}{$\begin{array}{c}\text { хозяйс- } \\
\text { тва всех } \\
\text { катего- } \\
\text { рий }\end{array}$} & \multicolumn{2}{|c|}{ в том числе: } & \multirow{2}{*}{$\begin{array}{c}\text { хозяйс- } \\
\text { тва всех } \\
\text { катего- } \\
\text { рий }\end{array}$} & \multicolumn{2}{|c|}{ в том числе: } & \multirow{2}{*}{$\begin{array}{c}\text { хозяйс- } \\
\text { тва всех } \\
\text { катего- } \\
\text { рий }\end{array}$} & \multicolumn{2}{|c|}{ в том числе: } \\
\hline & & & $\mathrm{CXO}$ & $\begin{array}{c}\text { КФХи } \\
\text { ЛПХ }\end{array}$ & & $\mathrm{CXO}$ & $\begin{array}{c}\text { КФХи } \\
\text { ЛПХ }\end{array}$ & & $\mathrm{CXO}$ & $\begin{array}{c}\text { КФХ и } \\
\text { ЛПХ }\end{array}$ & & $\mathrm{CXO}$ & $\begin{array}{c}\text { КФХи } \\
\text { ЛПХ }\end{array}$ \\
\hline Всего & 628,2 & 1745,9 & 227,1 & 1517,8 & 3905,8 & 199,8 & 3706,0 & 1094,9 & 10,6 & 1084,3 & 13685,3 & 3581,0 & 10104,3 \\
\hline Морковь & 16,7 & 290,3 & 31,5 & 258,8 & 566,4 & 36,0 & 530,4 & 176,6 & 2,8 & 173,8 & 1408,3 & 467,2 & 941,1 \\
\hline Лук репчатый & 39,3 & 197,7 & 21,9 & 175,8 & 813,5 & 66,6 & 744,9 & 209,8 & 5,5 & 204,3 & 1642,1 & 372,6 & 1269,5 \\
\hline Чеснок & - & 36,1 & 0,0 & 36,1 & 44,9 & 0,8 & 44,1 & 55,5 & 0,3 & 55,2 & 212,0 & 2,4 & 209,6 \\
\hline $\begin{array}{l}\text { Капуста } \\
\text { кочанная }\end{array}$ & 89,5 & 360,3 & 27,2 & 333,1 & 546,1 & 16,0 & 530,1 & 147,0 & 0,3 & 146,7 & 2519,3 & 427,5 & 2091,8 \\
\hline Огурцы & 50,6 & 226,4 & 48,7 & 177,7 & 460,1 & 3,8 & 456,3 & 119,5 & 0,1 & 119,4 & 702,7 & 50,9 & 651,8 \\
\hline Томаты & 138,1 & 284,7 & 70,6 & 214,1 & 765,4 & 29,6 & 735,8 & 224,7 & 0,6 & 224,1 & 2070,6 & 554,1 & 1516,5 \\
\hline
\end{tabular}

СХО - с.-Х. организации, КФХ - крестьянско-фермерские хозяйства, лпХ - личные подсобные хозяйства 
так и самое низкое потребление $37,4 \%$ ниже уровня норматива.

Недостаток собственной продукции покрывается как за счет ввоза из других стран - членов Союза, так и за счет импорта из третьих стран (табл. 2).

В целом по ЕАЭС в период с 2015 по 2018 год наблюдался рост экспорта свежих овощей на 4,5\% и снижение импорта на $16,8 \%$, что обусловлено снижением объема импорта в Россию на 20,5\% и увеличением экспорта на 8\%.

В структуре импорта овощей из третьих стран на долю томатов приходится $42 \%$, лука - $14 \%$, перца сладкого - $12 \%$, огурца - 7\%, капусты - 6\%, моркови - 4\%, салата-латука - $2 \%$, прочих - $13 \%$.

Основные экспортеры овощных культур в страны - члены ЕАЭС Китай, Турция, Ирак и еще более 10 стран ближнего и дальнего зарубежья. На долю России приходится почти 2/3 импорта в Союз в натуральном выражении и от 59,9\% до $86,8 \%$ в стоимостном показателе в разрезе культур, в т.ч. по томату - 76,7\%, луку репчатому и чесноку - 78,5\%, капусте - 59,9\%, моркови, свекле столовой и другим корнеплодам - 81,4\%, огурцам и корнеплодам - 86,8\% [4].

Основные экспортеры томатов из третьих стран - Азербайджан, Китай, Марокко и Турция, лука Египет, Китай, Турция, Таджикистан, капусты - Китай, Узбекистан, Иран, Польша, моркови - Израиль, Китай, Узбекистан, огурцов - Иран, Азербайджан, Китай и Турция. В Россию наибольшие поставки томата из Китая, Турции, треть импорта - из Азербайджана, в Беларусь из Турции. Больше половины купленной моркови, свеклы столовой и других корнеплодов в Россию поставили Израиль и Китай. Казахстан эти культуры импортирует в основном из Китая и Узбекистана. Лидером поставок огурцов в страны ЕАЭС в 2018 году был Иран. Почти весь объем его поставок пришелся на Россию. В Казахстан наибольшие поставки огурца идут из Узбекистана, в Беларусь - из Украины.

Помесячная динамика импорта овощных культур свидетельствует об увеличении поставок и средней цены импорта по томатам с ноября по март, лука и моркови - с апреля по июль, капусты - с декабря по июнь, огурца - с октября по май. В период насыщения рынка внутренним предложением цена импорта, как правило, снижается практически в два раза. Исключение составляют морковь, средняя цена импорта которой в течение всего года остается на одном уровне $(\$ 0,4 / к г)$ и перец сладкий, средняя цена импорта которого в межсезонье увеличивается практически в два раза (до $\$ 1,5 /$ кг).

Переизбыток выращенной продукции страны - члены ЕАЭС продают в другие страны. На долю России приходится более половины экспорта каждого вида овощей, за исключением продаж лука репчатого и чеснока. Более 94\% продаж томатов, капусты, огурца странами Союза приходится на направление из России на Украину. Половина продаж лука и чеснока идет из России и 50\% из них на Украину. Армения продает лук в Бельгию. Казахстан 40\% экспорта этих культур отправляет в Латвию.

Удельный вес в стоимостном показателе по ЕАЭС по экспортируемым культурам колеблется от 0,1\% (в основном, по Армении) до 98,2\% (Россия), в том числе: по томатам на долю России приходится 95,7\%; по луку репчатому и чесноку России 50,4\%, Казахстану - 33,5\%, Беларуси - 12,5\%; капусте - России 97,0\%, Беларуси - 2,6\%; моркови, свекле столовой и другим корнеплодам - России 80,8\%, Беларуси $18,8 \%$; огурцам и корнишонам России 98,2\%, Беларуси - 1,7\%.
Импорт в стоимостном выражении превышает экспорт во всех странах по всем рассматриваемым культурам. Кроме того, цена за 1 кг экспортируемой продукции каждого вида в среднем в ЕАЭС в 3-4 раза ниже ввезенной по импорту. Сопоставление данных показало, что средняя цена экспорта меньше цены производителей. Таким образом, экспорт лишь уменьшает убытки, но не решает главную задачу - получение прибыли от производства овощей.

Рост объемов взаимной торговли свежими овощами в значительной степени был обусловлен введением Российской Федерацией в отношении ряда западных стран продовольственного эмбарго, что привело к наращиванию с 2014 года объемов поставок в государства - члены ЕАЭС и дальнейшего их направления на российский рынок.

За период 2014-2018 годов взаимная торговля (по вывозу) свежими овощами увеличилась в Армении в 2,2 раза, в Казахстане - в 1,3 раза, в Российской Федерации - почти в 2 раза. Около 77\% объема взаимной торговли (500 тыс. т в 2018 году) приходилось на поставки из Беларуси, при этом более 90\% объема взаимной торговли овощами направлены на рынок России. При взаимной торговле государств - членов ЕАЭС на долю томатов приходится 37\%, огурца - 16\%, моркови - 10\%, капусты и лука - по 6\%, прочих - 23\%.

Овощи населению продают в основном торговые сети. Из-за несовершенства сбыта и большой цепочки посредников потребительские цены в разы превышают цены производителей. Например, лук репчатый продается в Казахстане по цене, превышающей отпускную цену хозяйств в 2,1 раза, в России - в 2,3 раза, в Беларуси - в 4 раза, в Армении в 1,5 раза, а в Кыргызской Республике разница составляет 23\%. Цена на свеклу столовую разнится от $38 \%$

Таблица 2. Производство и потребление овощебахчевой продукции в странах ЕАЭС ( 2018 год, национальные государственные статистические службы государств - членов ЕАЭС)

\begin{tabular}{|c|c|c|c|c|c|c|}
\hline \multirow{2}{*}{ Страны ЕАЭС } & \multirow{2}{*}{$\begin{array}{c}\text { Численность } \\
\text { населения, } \\
\text { млн чел }\end{array}$} & \multirow{2}{*}{$\begin{array}{c}\text { Потребность } \\
\text { согласно } \\
\text { нормативам, } \\
\text { тыс. т }\end{array}$} & \multicolumn{2}{|c|}{$\begin{array}{c}\text { Производство фактическое, } \\
\text { тыс. т }\end{array}$} & \multicolumn{2}{|c|}{$\begin{array}{c}\text { Личное потребление, } \\
\text { фактическое, тыс. т }\end{array}$} \\
\hline & & & 2018 год & $\begin{array}{l}2019 \text { год } \\
\text { (прогноз) }\end{array}$ & 2018 год & $\begin{array}{c}2019 \text { год } \\
\text { (прогноз) }\end{array}$ \\
\hline Всего: & 201,0 & 29911,0 & 29289,1 & 29626,1 & 24944,1 & 25127,0 \\
\hline В т.ч. Армения & 3,0 & 657,0 & 1238,3 & 1341,1 & 617,1 & 616,1 \\
\hline Беларусь & 9,5 & 1330,0 & 1828,3 & 1606,0 & 1390,7 & 1392,4 \\
\hline Казахстан & 18,0 & 3942,0 & 6074,0 & 6221,0 & 5296,6 & 5373,0 \\
\hline Кыргызстан & 6,5 & 910,0 & 1353,5 & 1358,0 & 977,1 & 993,9 \\
\hline Российская Федерация & 164,8 & 23072,0 & 18795,0 & 19100,0 & 16662,6 & 16751,6 \\
\hline
\end{tabular}


в Армении до 2,8 раз в Беларуси и Казахстане, на морковь - от $40 \%$ в Армении до 2,9 раз в России. Среди стран Союза только в Кыргызской Республике доля производителя в цене магазина, за исключением огурцов, была не менее $50 \%$ за последние три года [5].

\section{Выводы}

Таким образом, можно констатировать, что создание ТС и ЕЭП обеспечило свободное перемещение товаров во взаимной торговле стран - членов Союза, создало благоприятные условия торговли с третьими странами. Принятые в отношении России санкции со стороны Евросоюза, США, Австралии, Канады, а также других стран и ответные меры, изложенные в указе Президента Российской Федерации В.В. Путина на запрет ввоза на территорию страны отдельных видов с. - х. сырья и продовольствия, в том числе свежих овощей, способствовало снижению импорта овощей на $16,8 \%$ и увеличению экспорта на 4,5\% странами - членами ЕАЭС. В то же время это привело к дальнейшему перераспределению импортных овощей на российский рынок. Из-за несовершенства сбыта и большой цепочке посредников потребительские цены в разы превышают цены производителей, как в России, так и в других странах - членах ЕАЭС. Большие объемы производства овощей в КФХ $(22,5 \%)$ и ЛПХ (62,6\%) свидетельствуют о мелкотоварном характере производства и низкой товарности производства овощей в странах ЕАЭС. Увеличение поставок томата и огурца, например, в Россию, с октября по май свидетельствует о недостатке площадей защищенного грунта для производства их в несезонный период, а скачкообразный рост поставок весной и в начале лета (март - июнь) капусты, лука, моркови - о недостатке мощностей хранения. Выход из создавшегося положения возможен для России при дополнительном строительстве до 1,2 тыс. га тепличных комплексов, затраты на которые сопоставимы с объемами импорта томата и огурцов в течение 3-5 лет (около \$0,9 млн ежегодно), строительства овощехранилищ емкостью 0,6 млн т (от \$160 до $\$ 260$ млн), что сопоставимо с годовым объемом импорта с марта по июнь капусты, лука и моркови, а также решения проблем диспаритета цен и мелкотоварного производства.

\section{Библиографический список}

1.Евразийский экономический союз (ЕАЭС) [Электронный pecypc] URL: http://www.eaeunion.org/. Дата обращения: 21.01.2020.

2.Дробышевский А.А., Буць А.А., Тряхов А.Н. Обзор овощеводства в государствах - членах Евразийского экономического союза за 2013-2017 годы // Евразийская экономическая комиссия «Департамент агропромышленной политики». М., 2018. 99 с.

3.Производственные показатели, внешняя и взаимная торговля государств - членов ЕАЭС овощами и продукцией их переработки [Электронный ресурс] URL: http://www.fao.org/faostat. Дата обращения: 21.01.2020.

4.Мировые тренды [Электронный ресурc] URL: https:// interagro.info/news/smi-o-nas/interagro-v-zhurnale-apk-news-. Дата обращения: 21.01.2020.

5.Евразийская экономическая комиссия [Электронный реcypc] URL: http://www.eurasiancommission.org. Дата обращения: 23.01.2020.

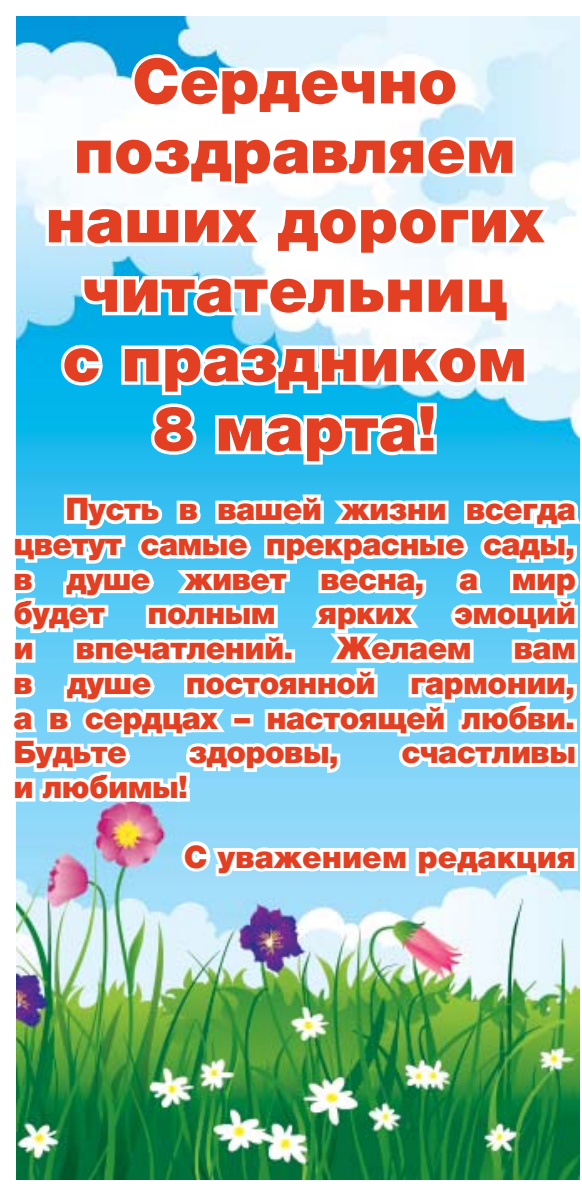

\section{References}

1.Eurasian economic Union (EEU) [Web resource] URL: http:// www.eaeunion.org/. Date of access: 23.01.19 (In Russ.).

2.Drobyshevskii A.A., Buts' A.A., Tryakhov A.N. Review of vegetable growing in the member States of the Eurasian economic Union for 2013-2017. Eurasian economic Commission Department of agroindustrial policy. Moscow, 2018. 99 p. (In Russ.).

3.Production indicators, foreign and mutual trade of the EAEU member States in vegetables and products of their processing [Web resource] URL: http://www.fao.org/faostat. Date of access: 23.01.19 (In Russ.).

4.World trends [Web resource] URL: https://interagro.info/news/ smi-o-nas/interagro-v-zhurnale-apk-news-/. Date of access: 23.01.19 (In Russ.).

5.Eurasian economic Commission [Web resource] URL: http:// www.eurasiancommission.org. Date of access: 23.01.19 (In Russ.).

\section{Об авторах}

Разин Анатолий Федорович, доктор экономич. наук, гл.н.с., руководитель, научный руководитель. E-mail: 777razin@rambler.ru

Мещерякова Раиса Анатольевна, канд. с.-х. наук, С.н.с. E-mail: vniioh@yandex.ru

Шатилов Максим Витальевич, канд. с.-х. наук, н.c.E-mail: astronom777@ya.ru Разин Олег Анатольевич, канд. с.-х. наук, н.с. (ФГБНУ ФНЦО). E-mail: oleg.rasin@gmail.com

Сурихина Татьяна Николаевна, м.н.с. E-mail: 9153756862@mail.ru Телегина Галина Алексеевна, м.н.с. E-mail: teleginaga@mail.ru

Всероссийский научно-исследовательский институт овощеводства - филиал ФГБНУ «Федеральный научный центр овощеводства» (ФНЦО)

\section{Author details}

Razin A.F., Doctor Sci. (Econ.), chief research fellow, director, scientific adviser. E-mail: 777razin@rambler.ru

Meshcheryakova R.A., Cand. Sci. (Agr.), senior research fellow. E-mail:vniioh@yandex.ru

Shatilov M.V., Cand. Sci. (Agr.), research fellow. E-mail: astronom777@ya.ru

Razin O.A., Cand. Sci (Agr.)., research fellow, (FSBSI FSVC). E-mail: oleg.rasin@gmail.com

Surikhina T.N., junior research fellow.E-mail: 9153756862@mail.ru

Telegina G.A., junior research fellow. E-mail: teleginaga@mail.ru All-Russian Research Institute of Vegetable Growing - branch of Federal Scientific Centre of Vegetable Growing 